Relations industrielles

Industrial Relations

\title{
Regulating Conflict in Public Sector Labour Relations
}

The Ontario Experience (1984-1993)

\section{La régulation du conflit dans les relations du travail}

l'expérience du secteur public de l'Ontario (1984-1993)

\section{Regulando el conflicto en las relaciones laborales del sector publico}

\author{
La experiencia de Ontario 1984-1993
}

\section{Robert Hebdon et Maurice Mazerolle}

Volume 58, numéro 4, automne 2003

URI : https://id.erudit.org/iderudit/007821ar

DOI : https://doi.org/10.7202/007821ar

\section{Aller au sommaire du numéro}

\section{Éditeur(s)}

Département des relations industrielles de l'Université Laval

ISSN

0034-379X (imprimé)

1703-8138 (numérique)

Découvrir la revue

Citer cet article

Hebdon, R. \& Mazerolle, M. (2003). Regulating Conflict in Public Sector Labour Relations: The Ontario Experience (1984-1993). Relations industrielles /

Industrial Relations, 58(4), 667-686. https://doi.org/10.7202/007821ar

\section{Résumé de l'article}

La solution efficace des conflits dans le secteur public fortement syndiqué au Canada continue à retenir l'intérêt des chercheurs et des décideurs publics. Une préoccupation centrale de nos jours porte sur les procédures de solution des conflits inhérents à la restructuration gouvernementale dans le secteur des services en Amérique du Nord. Au Canada, dans un milieu syndiqué, trois formes de restructuration du secteur public ont été répertoriées impliquant soit une approche coopérative, soit une approche " opposionniste », ou bien celle de l'imposition d'un règlement par voie de législation (Swimmer 2001). Étant donné un tel contexte de restructuration, un besoin plus urgent se présente alors d'un analyse des procédures de solution de conflits dans le secteur public. Par exemple, l'arbitrage des différends, qui est la manière habituelle de solutionner les conflits dans le secteur public en général, fait de plus en plus lobjet d'un examen rigoureux à titre de mécanisme efficace de règlement des conflits suite à des changements fondamentaux des condi
de travail (Rose 1994 ; Lund et Maranto 1996 ; Hebdon 1996; Warrian 1996 ; Adell, Grant et Ponak 2001). Nous de travail (Rose 1994 ; Lund et Maranto 1996 ; Hebdon 1996 ; Warrian 1996 ; Adell, Grant et Ponak 2001). Nous
ré-évaluons l'efficacité de l'arbitrage à travers les diverses législations qui encadrent la solution des conflits dans le ré-évaluons l'efficacité de l'arbitrage à travers les diverses législations qui encadrent la solution des conflits dans le
secteur public. En reprenant un ensemble de données semblable à celui retenu par Rose et Piczak (1996), nous procédon à une analyse de régression multivariée plus rigoureuse et, en ventilant les données, nous jetons un éclairage sur les aspects plus comportementaux de l'arbitrage obligatoire.

L'arbitrage obligatoire : un cadre théorique. L'arbitrage obligatoire des différends a fait l'objet de recherche en Amérique du Nord, un contexte ou ce mécanisme se presente comme une dernière possibilité parmi plusieurs pour apporter une solution défnitive aux mésententes impliquant des fonctionnaires dont les services sont quallfés dessentiels par des lois et des agences ad plupart des conflits dans le secteur public se terminent par une sorte de commission d'enquête ou par une médiation qui ne lie pas les parties (Hebdon et Stern 2003). Au Canada, le dernier reours lorsque l'impasse persiste, consiste soit ̀̀ offrir un droit limité à la grève, soit à recourir à l' l'imposition de l'arbitrage obligatoire, ou bien le choix entre l'arbitra ou le recours à la grève (Adell, Grant et Ponak 2001).

Les travaux de recherche ont retenu plusieurs critères afin d'évaluer l'efficacité de la solution des conflits : les Les travaux de recherche ont retenu plusieurs critères afin d'évaluer l'efficacité de la solution des conflits : les
perceptions des parties, la fréquence du recours à un mécanisme et son impact sur la négociation collective ; l'aptitude à perceptions des parties, la fréquence du recours à un mécanisme et son impact sur la négociation collective ; l'aptitude Ponak 2001).

Les données et les méthodes. Pour effectuer cette analyse, nous avons retenu comme principale base de données celle du ministère du Travail de l'Ontario qui porte sur 42926 négociations conduites en Ontario entre les années 1984 et 1993. Les données couvrent toutes les unités d'accréditation de toutes les catégories au plan de la taille dans le secteur privé (incluant celui de la construction) et également dans le secteur public provincial au complet pour la période allant de 1984 à 1993 . Les instances de règlement sont regroupées sous deux catégories mutuellement exclusives : celles ré́glées 1984 à 1993. Les instances de règlement sont regroupeess sous deux catégories mutuellement exclusives : celles réglées
après une impasse (une grève, un arbitrage de différends ou une législation de retour au travail); celles négociées librement (avec l'assistance directe ou non d'une tierce partie).

Conclusion. Cet ensemble de données d'une grande portée permet aux chercheurs de jeter un regard sur les modèles de solution des conflits de toutes les unités d'accréditation de l'Ontario au cours d'une période de dix ans. Qu'avons-nous retenu de tout cela ? Une conclusion fondamentale est à l'effet que les unités de négociation couvertes par la loi qui
requiert l'arbitrage obligatoire des différends font face à une impasse dans une proportion de 8,7 à 21,7 pour cent plus grande que les unités des secteurs avec droit de grève. Même après avoir tenu compte de la juridiction de la législation, de la centrale syndicale, de la taille de l'unité de négociation, de l'occupation, de la durée de la convention, de la tendance dans le temps et du statut de temps partiel, il devient fort évident que l'arbitrage obligatoire a un effet de refroidissemen sur le processus de négociation. L'impossibilité d'en arriver à un règlement négocié est particulièrement prononcée dan le secteur de la santé, plus particulièrement dans les établissements hospitaliers. Nos résultats nous invitent à remettre en question le recours à l'arbitrage obligatoire dans un contexte de négociation centralisée : la structure centralisée semblait aggraver cet effet de refroidissemen

D’un autre côté, la période 1984-1993 envisagée par cette étude reflète bien la situation du secteur public, étant donné les contraintes financières et les impératifs politiques de restructuration des gouvernements de toute couleur politique. Par conséquent, on peut prétendre que ces conclusions ne sont pas directement applicables à d'autres juridictions en Amérique du Nord. Notre analyse laisse croire que l'arbitrage conventionnel des différends, une fois mis à l'essai, ne réussit pas à déboucher sur un taux satisfaisant d'ententes à l'amiable. Nous pouvons soutenir de façon évidente que l'arbitrage a exercé une influence marquee sur le comportement de negociation des syndicats en augmentant le taux de mésententes. L'effet d'influence ainsi observé devient d'autant plus significatif que le syndicat oeuvre dans le secteur de l'arbitrage et qu'il représente une proportion de l'activité totale de négociation. Cette observation apporte un support a libret de dependance par
Tous droits réservés @ Département des relations industrielles de l'Université Laval, 2003
Ce document est protégé par la loi sur le droit d'auteur. L’utilisation des services d’Érudit (y compris la reproduction) est assujettie à sa politique d'utilisation que vous pouvez consulter en ligne.

https://apropos.erudit.org/fr/usagers/politique-dutilisation/ 


\title{
Regulating Conflict in Public Sector Labour Relations
}

The Ontario Experience (1984-1993)

\author{
RoBERT HEBdon \\ Maurice Mazerolle
}

\begin{abstract}
Using a comprehensive collective bargaining data set, we examine dispute resolution patterns of all bargaining units in the province of Ontario over a 10-year period. A central finding is that bargaining units covered by legislation requiring compulsory interest arbitration arrive at impasse 8.7 percent to 21.7 percent more often than bargaining units in the right to strike sectors. Even after controlling for legislative jurisdiction, union, bargaining unit size, occupation, agreement length, time trend, and part-time status, strong evidence was found that compulsory arbitration has both chilling and dependence effects on the bargaining process. The problem of failure to reach negotiated settlements is particularly acute in the health care sector, especially among hospitals. Our results also call into question the use of interest arbitration in a central bargaining context. The centralized structure appears to exacerbate the negative effects of interest arbitration.
\end{abstract}

The effective resolution of disputes in the highly unionized public sectors in Canada and in the United States continues to command the interest of policymakers and researchers. A central concern today is the impact of government restructuring of service delivery in North America on impasse resolution procedures. In Canada, in a unionized environment, three forms of public sector restructuring have been identified which involve

- Hebdon, R., Faculty of Management, McGill University, Montréal, Quebec, $<$ robert.hebdon@mcgill.ca>.

MAZERolle, M., School of Business Management, Ryerson University, Toronto, Ontario, $<$ mmazerol@ ryerson.ca>. 
either a cooperative approach, an adversarial bargaining, or an imposed solution through legislation (Swimmer 2001). Given this restructuring context, there is an even greater need to examine weaknesses in public sector dispute resolution procedures. For example, interest arbitration, a common form of resolving bargaining impasses in much of the public sector, has come under increasing scrutiny as an effective mechanism for resolving disputes over fundamental changes in conditions of employment (Rose 1994; Lund and Maranto 1996; Hebdon 1996; Warrian 1996; Adell, Grant and Ponak 2001).

It is conventional wisdom in industrial relations that the most enduring settlement is one that is freely negotiated between management and labour. This fundamental labour relations tenet assumes even greater significance in today's climate of change. Only the parties themselves (labour and management) are positioned to fashion the mutually acceptable solutions so necessary for enduring changes not only in the conditions of employment, but perhaps more importantly, to the relationship itself. Thus, a critical yardstick for measuring the performance of dispute resolution in a changing environment is the rate of freely negotiated settlements versus those imposed by a third party.

In an examination of compulsory interest arbitration in Ontario, Rose and Piczak (1996) found that it produced lower settlement rates, particularly in the Hospital sector. They also discovered that there was wide variation in arbitration performance by sector: Police, Fire, Government, and Hospital. We reexamine the effectiveness of arbitration through the various legislative frameworks intended to regulate public sector dispute resolution. Using a data set similar to that of Rose and Piczak (1996), we perform a more rigorous multivariate regression analysis and then, by disaggregating the data, we shed light on some of the more behavioural aspects of compulsory arbitration.

\section{THEORETICAL FRAMEWORK: COMPULSORY ARBITRATION}

Compulsory interest arbitration has been researched in a North American context where arbitration is only one option among many as a final dispute resolution procedure. Thus for public employees who are deemed essential by the relevant provincial, state, or federal bargaining legislation or administrative agency arbitration is not the only available strike replacement option. In the U.S., for example, most public sector disputes end in some form of non-binding fact-finding or mediation (Hebdon and Stern 2003). In Canada, the final step, if there is an impasse, is to either provide a limited right to strike, impose compulsory arbitration, or, 
in a few cases, offer a choice of arbitration or striking (Adell, Grant and Ponak 2001).

Research has focused on several criteria for evaluating dispute resolution effectiveness: the views of the parties; frequency of utilization and impact on collective bargaining; ability to reduce conflict and prevent strikes; and the success rate in resolving disputes (Stern 1966; Adell, Grant and Ponak 2001). To these criteria, in light of the growing consensus surrounding freedom of association as a human right, we add the requirement that the final dispute resolution procedure must meet the international labour standards established by the United Nations and the International Labour Organization (ILO) for essential public employees (see, for example, Adams 2002; Gross 2003).

\section{Freedom of Association as a Human Right}

Freedom of association is a core labour standard of the ILO. Under this standard, where public services are deemed essential and the right to strike is removed by statute, an impartial arbitration process must be a minimum substitute in order to satisfy international human rights norms. More than simply being lofty ideals, the ILO standards on freedom of association have been cited by several Canadian courts as important legal precepts (see Dunmore v. Ontario (Attorney General), (2001) 207 D.L.R. (4th) 193 (S.C.C.)) A court case that bears directly on the Hospital arbitration procedures examined in this paper also relied, in part, on the ILO standard as applied to the public sector. In 1998, the Minister of Labour under the Harris conservative government appointed four retired judges to chair several arbitration boards under the Hospital Arbitration Act. In upholding the unions' challenge in November 2000, the Ontario Court of Appeal cited the freedom of association provisions of the International Labour Office (C.U.P.E. v. Ontario (Minister of Labour), ONCA C32230 (200011-21)). The Court of Appeal said:

[44] Further support is found in Freedom of Association, Digest of decisions and principles of the Freedom of Association Committee of the Governing Body of the International Labour Office (Geneva: International Labour Office 1996). It says:

547. As regards the nature of appropriate guarantees in cases where restrictions are placed on the right to strike in essential services and the public service, restrictions on the right to strike should be accompanied by adequate, impartial and speedy conciliation and arbitration proceedings in which the parties concerned can take part at every stage and in which the awards, once made, are fully and promptly implemented.....

549. In mediation and arbitration proceedings it is essential that all the members of the bodies entrusted with such functions should not only be strictly 
impartial but, if the confidence of both sides, on which the successful outcome even of compulsory arbitration really depends, is to be gained and maintained, they should also appear to be impartial both to the employers and to the workers concerned.

The requirement in paragraph 547 above would call into question those final dispute settlement procedures that fail to provide an impartial, final, and binding solution to public sector bargaining. If applied in a North American context, numerous jurisdictions would immediately fail this basic test. In Ontario, over the period covered by this paper, public employees could either strike or arbitrate depending on the particular statute. Note also that according to the ILO, only truly essential public employees ought to be denied the right to strike. In Ontario, in addition to police and firefighters, all health care employees and civil servants were denied the right to strike. ${ }^{1}$

\section{Industrial Conflict and Strikes}

In an attempt to identify the best legislative approach, research has centered on the costs and benefits of various dispute resolution procedures. Research shows, for example, that strike ban laws, especially where arbitration is the final step in the bargaining process, have been effective in preventing strikes (Ichniowski 1982; Olson 1986; Currie and McConnell 1991). Implicit in these studies, is the assumption that strikes are synonymous with industrial conflict. This assumption is problematic; however, if the no-strike laws decrease strikes but have the unintended effect of increasing other expressions of industrial conflict. There is mounting evidence, for example, of a higher number of grievances and grievance arbitrations under no-strike laws in Ontario and the U.S. municipal sector (Hebdon and Stern 1998, 2003). Hebdon and Stern (2003) also found that arbitration laws had no effect in reducing strikes or job actions (e.g., sickouts, slowdowns, working-to-rule actions, and wildcat walkouts). Moreover, job actions levels and union political activity were found to be higher under states with final offer arbitration ${ }^{2}$ as the final step. This finding may have implications for this study since there is evidence that final offer arbitration does seem to reduce the chilling effect of arbitration by producing higher settlement rates (Hebdon 1996). More research is needed, but it may be that the beneficial effect of final offer arbitration in producing higher

1. Crown or direct employees of the Ontario Government were granted the right to strike on January 1, 1994, after the period under analysis in this study.

2. A form of interest arbitration where the arbitrator must choose either the union or employer final offer. Final offer arbitration has been used in an ad hoc way in Canada to settle some public sector strikes. 
settlement rates as compared to conventional arbitration is offset by the negative impact on the relationship in terms of subsequent adversarial negotiations and difficult contract administration in the form of more grievances.

\section{Views of the Parties}

In an examination of different strike models through the eyes of the parties involved, Adell, Grant and Ponak (2001) conclude that:

[T] he designation model is most appropriate in sectors where work stoppages pose an immediate and substantial threat to public health and safety. In those sectors (health care, for example), the burden which the designation process imposes on collective bargaining is outweighed by the need to ensure essential service coverage. Our findings suggest that the designation model can meet that need quite well without discouraging the voluntary settlements and broadly acceptable outcomes that are central to an effective collective bargaining system.

\section{Frequency of Utilization, Settlement Rates, and Impact on Collec- tive Bargaining}

While the literature on the negative aspects of compulsory arbitration is vast, there is a generally accepted belief that by unduly inhibiting the ability of the parties to freely negotiate settlements, arbitration is alleged to have "chilling" and "narcotic" effects on bargaining (Ponak and Falkenberg 1989; Hebdon 1996). The chilling effect may be caused by the parties' perception that arbitrators are likely to take a split-the-difference approach that falls somewhere between the parties' last bargaining positions. The chilling effect could also come about simply by the parties failing to make the tough tradeoffs often necessary in collective bargaining, especially in difficult economic times. This repeated use of arbitration may, over time, cause a further dependency (hence the narcotic effect) to emerge, based, in part, on the parties' loss of the ability to negotiate and on having a convenient scapegoat in the form of an arbitrator should the outcome not be the preferred one. The option of avoiding difficult compromises is less available under right-to-strike laws where the impending prospect of a strike may impose mutual responsibility on the parties.

The literature on these negative effects of arbitration is mixed. In an examination of arbitration usage rates in eight U.S. states and in New York City, Lester (1984) found little evidence of chilling or narcotic effects. ${ }^{3}$

3. An exception was a 29 percent usage rate of arbitration for police and fire employees in Pennsylvania (Lester 1984: 205). 
However, other studies have generally found the highest impasse rates under conventional arbitration, somewhat lower ones for final-offer arbitration, ${ }^{4}$ and lower rates still for jurisdictions with the right to strike (Ponak and Falkenberg 1989; Currie and McConnell 1991; Hebdon 1996).

Previous studies suffer from four deficiencies. First, public-private comparisons generally fail to control for occupational, industry, legislative, union and other differences. Second, studies almost universally exclude the construction industry. Third, these studies typically compare dispute rates across, not within, states with different impasse resolution procedures. Since other state-specific differences (e.g., bargaining laws) are likely, it is difficult to make reliable inferences from this research (Olson 1994). Finally, data limitations restrict samples to bargaining units of either 1,000, 500 , or (in a few instances) of 200 or more employees. For example, previous studies using Canadian contract settlement data have typically been restricted to large bargaining units of 500 or more employees (e.g., Currie and McConnell 1991), or larger samples of units with 200 or more employees (e.g., Gunderson, Kervin and Reid 1986). This omission of bargaining units with less than 200 employees is particularly significant when applied to the large data set used for this paper $(42,926$ settlements from 1984 to 1993), since it would exclude from analysis 87 percent of agreements (covering 27 percent of employees). Moreover, the omission of small bargaining units prevents a full examination of the impact of structural aspects such as centralization of bargaining on dispute resolution.

Similar studies with U.S. contract data have utilized even larger bargaining units of more than 1000 employees (e.g., Gramm 1987; McConnell 1987). Few empirical studies of dispute resolution could be found involving bargaining units with less than 200 employees. Consequently, surprisingly little is known about how collective bargaining is practiced in small firms (Cutcher-Gershenfeld, McHugh and Carter 1996).

This study attempts to fill these gaps by adding such controls as contract duration, union, and occupation, by including the construction sector, and by examining impasse rates (strikes and interest arbitrations) for bargaining units of all sizes.

\section{History of Bargaining Structure}

The current legislative frameworks in the United States and Canada were founded on the Wagner Act model of industrial relations. This model

4. Under final offer arbitration, the arbitrator is forced to select either of the parties' last offers, thereby preventing a split-the-difference approach. 
was primarily designed for private sector industries with largely male, permanent workforces engaged in standardized mass production with fixed narrow job skills and rigid boundaries between management and workers (Warrian 1995). Collective bargaining was more often than not characterized by the presence of large bargaining units and pattern bargaining within a more stable industrial model of the economy. A defining feature of the Wagner industrial model was its awarding of exclusive bargaining rights to unions for the workers that they organized. This resulted in a multiplicity of separate bargaining units even among employees with the same employer. In response, some parties, especially in the public sector, have created more centralized bargaining structures. ${ }^{5}$

"One size fits all" solutions, which are prominent features of centralized bargaining structures, are problematic in that they do not allow the parties the flexibility to fashion a tailor-made solution to localized problems. The resulting inability to satisfactorily deal with issues of this nature results in additional stress being placed on the system. In addition to the structural challenges of delivering meaningful responses to quite legitimate local concerns, centralized bargaining becomes especially problematic in accommodating the restructuring imperatives of the public sector. Thus, in addition to the choice of dispute resolution procedure, the degree of centralization and the structure of bargaining may have important effects on the parties' abilities to work out their own solutions. It is within this context that we examine the bargaining experience in Canada's largest province, Ontario.

\section{Ontario Overview}

In the period under examination in this paper (1984-93), we point out that, to some extent, restructuring of services had already begun. Faced with declining revenues and increased deficits, the province of Ontario's public sector had been under intense pressures to reduce costs, create efficiencies, and alter the form of service and program delivery. This undertaking took place within the then existing legislative framework that governed collective bargaining. In examining this framework's responsiveness to these pressures, our focus will be on the effectiveness of dispute resolution procedures available to the parties. Of the eight Ontario laws that provided for the resolution of interest disputes over the period 19841993, four provide for binding arbitration (over Ontario government, health care, police, and fire employees) and four laws provided for the right to strike (for construction, college, school board, and employees in the

5. The construction and hospital sectors are examples of centralized structures in Ontario. 
remainder of private and public sectors). Within this unique legislative arrangement, a comparison of arbitration and strike rates between these eight sectors provides a measure of the system's responsiveness in allowing labour and management to respond to the challenges posed by these restructuring efforts. In addition, it also allows for a unique reexamination of the possible "chilling" and "narcotic" effects that compulsory arbitration may have had on bargaining within large segments of the public sector. To do this, we undertook an examination of the resolution of all 42,926 collective bargaining settlements that occurred in the province of Ontario during the period 1984-1993. The reason for not including the data for the period following 1993 is that in that year, the government in power at that time imposed a three-year social contract for the entire public sector including municipalities, universities, schools, hospitals and the civil service. As a result, wages, benefits, and working conditions were legislated and the right to strike was removed.

\section{DATA AND METHODS}

The primary database used for conducting this analysis is the Ontario Ministry of Labour's collective bargaining database which consists of 42,926 labour-management negotiations conducted in Ontario between 1984 and 1993. The data cover all bargaining units in all size categories for both the private sector (including construction) and the entire provincial public sector for the period 1984 to $1993 .{ }^{6}$ The settlement stages are grouped into two mutually exclusive categories: settled after an impasse (strike, interest arbitration or back to work legislation), and freely negotiated (with or without direct, third-party assistance).

\section{Dependent Variables}

In order to determine whether the relationships between bargaining unit size, independent unions and contract settlement stages revealed by the tabular data are robust to a myriad of other factors that can influence bargaining, we estimate a multinomial logit settlement stage model. The dependent variable in our analysis is trichotomous, taking a value of 1 if the collective agreement was negotiated without an impasse or third-party assistance, a value of 2 if the contract was settled with the assistance of a third-party (e.g., after mediation, conciliation, and/or fact-finding), and a value of 3 if the agreement was reached following an impasse (strike or

6. Excludes settlements in the Federal sector covering private and public employees in Ontario and a small number of those under Ontario's wage control program. 
interest arbitration). The model provides estimates of the marginal impacts of the independent variables on the probabilities of experiencing an impasse or use of third-party assistance, relative to reference outcome of settlement through direct negotiation.

\section{Independent Variables}

Dichotomous independent variables were then created to reflect the various legislated bargaining regimes that apply to collective bargaining in the province of Ontario. It should be noted that the omitted reference category for the various public legislative regimes is the Ontario Labour Relations Act, OLRA (excluding construction). In addition to the legislative variables, a series of dummy variables was also included to control for bargaining unit size, union, part-time status, length of prior agreement, and time trend.

\section{Chilling Effects}

The richness of this data set permits a more comprehensive analysis of the chilling effect than has been previously undertaken. We examine four ways that this effect might show up. First, the more traditional approach is to compare usage rates of arbitration and strike. To analyze this effect on the bargaining process, we sorted the data into strike and arbitration sectors. Table 1 sets out these eight legislative sectors in Ontario.

TABLE 1

Ontario Collective Bargaining Laws (1984-1993)

\begin{tabular}{lll}
\hline Sector & \multicolumn{1}{c}{ Law } & Strike / Arbitration \\
\hline Fire & Firefighters Act & Arbitration \\
Police & Police Act & Arbitration \\
Colleges & Colleges Collective Bargaining Act & Strike \\
Health Care & Hospital Labour Disputes Arbitration Act & Arbitration \\
Construction & Construction Industry / Sections of OLRA & Strike \\
Ontario & Crown Employees Collective Bargaining Act & Arbitration \\
Government & & \\
School Boards & School Boards and Teachers Collective & Strike \\
& Negotiations Act & \\
OLRA & Ontario Labour Relations Act & Strike \\
\hline
\end{tabular}




\section{RESULTS}

Table 2 provides multinomial logit regression results for our dispute resolution dependent variables. The results under Collective bargaining law show substantially different patterns. Focusing on the arbitration law variables ONTARIO GOVERNMENT, HEALTH CARE, POLICE, AND FIRE, and controlling for a number of factors, arbitration laws all had significantly higher impasse rates compared to the reference category of the OLRA (Ontario Labour Relations Act). The magnitudes of these effects were substantial ranging from 8.7 percent higher in the Ontario Government sector to 21.7 percent higher in the fire sector.

TABLE 2

Multinomial Logit Estimates of Bargaining Settlement Stage in Ontario (1984-1993)

\begin{tabular}{|c|c|c|c|c|c|c|}
\hline \multirow[b]{2}{*}{ Independent Variables } & \multicolumn{3}{|c|}{ Third Party } & \multicolumn{3}{|c|}{ Impasse } \\
\hline & $\begin{array}{c}\text { Logit } \\
\text { Coefficient }\end{array}$ & $t$ statistic & $\begin{array}{c}\text { Marginal } \\
\text { Effect }\end{array}$ & $\begin{array}{c}\text { Logit } \\
\text { Coefficient }\end{array}$ & t statistic & $\begin{array}{c}\text { Marginal } \\
\text { Effect }\end{array}$ \\
\hline \multirow{2}{*}{\multicolumn{7}{|c|}{$\begin{array}{l}\text { Collective Bargaining } \\
\text { Law }\end{array}$}} \\
\hline & & & & & & \\
\hline Health Care & -.138 & -3.12 & -.082 & 2.544 & 44.74 & .166 \\
\hline Ontario Government & -1.395 & -4.62 & -.313 & .906 & 3.72 & .087 \\
\hline Police & -2.671 & -15.13 & -.595 & 1.491 & 16.04 & .152 \\
\hline Fire & -5.446 & -5.44 & -1.184 & 1.600 & 13.41 & .217 \\
\hline Colleges & -.927 & -1.29 & -.194 & -.105 & -.13 & .013 \\
\hline School Boards & -2.063 & -23.45 & -.396 & -1.875 & -11.20 & -.077 \\
\hline Construction & -.801 & -6.71 & -.152 & -.845 & -3.11 & -.038 \\
\hline \multicolumn{7}{|l|}{ Bargaining Unit Size } \\
\hline 20 and under & -.768 & -12.30 & -.130 & -1.539 & -17.25 & -.083 \\
\hline 21 to 49 & -.282 & -4.43 & -.037 & -1.088 & -11.98 & -.064 \\
\hline 50 to 99 & -.078 & -1.20 & .001 & -.812 & -8.79 & -.051 \\
\hline 100 to 149 & -.051 & -.72 & .003 & -.652 & -6.49 & -.041 \\
\hline 150 to 199 & -.026 & -.32 & .003 & -.411 & -3.60 & -.026 \\
\hline 200 to 299 & .076 & .95 & .022 & -.303 & -2.73 & -.021 \\
\hline 300 to 499 & .016 & .19 & .011 & -.378 & -3.27 & -.025 \\
\hline (500 or more omitted) & & & & & & \\
\hline \multicolumn{7}{|l|}{ Union } \\
\hline CAW & -.962 & -13.23 & -.222 & .903 & 9.70 & .078 \\
\hline USWA & .429 & 9.85 & .074 & .782 & 9.29 & .041 \\
\hline CEP & .321 & 2.46 & .069 & -.489 & -.16 & -.010 \\
\hline TMSTER & .355 & 8.03 & .070 & .258 & 2.42 & .009 \\
\hline CUPE & -.076 & -2.05 & -.014 & -.113 & -1.67 & -.006 \\
\hline OPSEU & .143 & 2.19 & .020 & .474 & 4.59 & .027 \\
\hline SEIU & .042 & .73 & .015 & .354 & 4.83 & .022 \\
\hline
\end{tabular}


TABLE 2 (continued)

\begin{tabular}{|c|c|c|c|c|c|c|}
\hline \multirow[b]{2}{*}{ Independent Variables } & \multicolumn{3}{|c|}{ Third Party } & \multicolumn{3}{|c|}{ Impasse } \\
\hline & $\begin{array}{l}\text { Logit } \\
\text { Coefficient }\end{array}$ & t statistic & $\begin{array}{l}\text { Marginal } \\
\text { Effect }\end{array}$ & $\begin{array}{c}\text { Logit } \\
\text { Coefficient }\end{array}$ & t statistic & $\begin{array}{c}\text { Marginal } \\
\text { Effect }\end{array}$ \\
\hline INDPRIV & -1.893 & -12.33 & -.367 & -1.576 & -4.37 & -.062 \\
\hline INDPUB & -1.654 & -9.66 & -.302 & -2.242 & -4.79 & -.109 \\
\hline UNSTAFF & -1.117 & -5.77 & -.217 & -.893 & -1.75 & -.034 \\
\hline CLAC & -.453 & -3.29 & -.075 & -1.003 & -5.17 & -.055 \\
\hline IWA & .352 & 3.68 & .058 & .800 & 4.56 & .044 \\
\hline UFCW & .535 & 10.01 & .103 & .491 & 4.77 & .020 \\
\hline $\begin{array}{l}\text { RWDSU } \\
\text { (all others omitted) }\end{array}$ & .554 & 8.55 & .104 & .643 & 4.59 & .030 \\
\hline \multicolumn{7}{|l|}{ Employment Status } \\
\hline Part Time & .195 & 3.40 & .033 & .374 & 5.69 & .020 \\
\hline $\begin{array}{l}\text { Mixed Full/Part Time } \\
\text { (full time omitted) }\end{array}$ & -.164 & -4.95 & -.032 & -.126 & -2.52 & -.005 \\
\hline \multicolumn{7}{|l|}{ Job Type } \\
\hline White Collar & .006 & .17 & .006 & -.219 & -3.31 & -.014 \\
\hline Professional & .542 & 10.37 & .102 & .577 & 8.03 & .026 \\
\hline $\begin{array}{l}\text { Technical } \\
\text { (blue collar omitted) }\end{array}$ & & & & & & \\
\hline \multicolumn{7}{|l|}{ Contract Duration } \\
\hline One-Year Agreement & -.162 & -4.56 & -.033 & -.051 & -.79 & .000 \\
\hline $\begin{array}{l}\text { Two-Year Agreement } \\
\text { (three-years or more } \\
\text { omitted) }\end{array}$ & .045 & 1.42 & .002 & .353 & 6.30 & .022 \\
\hline \multicolumn{7}{|l|}{ Time Trend } \\
\hline Year 84 & -.050 & -1.04 & .006 & -.806 & -9.54 & -.051 \\
\hline Year 86 & -.015 & -.30 & -.009 & .267 & 3.99 & .175 \\
\hline Year 87 & .019 & .39 & .012 & -.362 & -4.70 & -.024 \\
\hline Year 88 & .117 & 2.45 & .047 & -1.082 & -13.21 & -.072 \\
\hline Year 89 & .157 & 3.22 & .038 & -.212 & -2.83 & -.017 \\
\hline Year 90 & .018 & .35 & .004 & -.030 & -.39 & -.002 \\
\hline Year 91 & .300 & 6.26 & .076 & -.628 & -8.05 & -.047 \\
\hline Year 92 & .081 & 1.60 & .021 & -.165 & -2.08 & -.012 \\
\hline Year 93 & .194 & 3.66 & .038 & .162 & 2.08 & .006 \\
\hline \multicolumn{7}{|l|}{ (Year 85 omitted) } \\
\hline Constant & -0.184 & -2.53 & & -1.569 & -14.22 & \\
\hline $\mathrm{N}$ & 42926 & 42926 & & 42926 & 42926 & \\
\hline Equation Statistics & $\pi^{2}=$ & & & & & \\
\hline & 11649.32 & & & & & \\
\hline
\end{tabular}

Impasse rates in the education sector (SCHOOL BOARDS), which has the right to strike, were 7.7 percent less than those in our omitted category of Ontario Labour Relations Act (right to strike). 
The HEALTH CARE sector revealed arbitration rates 16.6 percent higher than strike rates under the OLRA. This result is even more important because this sector accounts for about 75 percent (6995 out of 8973) of all settlements under arbitration laws. For these reasons, a closer examination of this health care sector is warranted.

Table 3 divides the health care sector that falls under the jurisdiction of the Hospital Labour Disputes Arbitration Act into three sub-sectors with the number of settlements within each sector in parentheses: hospitals (4269), nursing homes (2656), and hospital services - heating, laundry, and food (70). The hospital sub-sector is characterized by an elaborate system of central bargaining whereby locals of major unions (ONA, SEIU, CUPE, and OPSEU) and their respective hospitals voluntarily agree to be bound by a common framework agreement. Central bargaining in this sub-sector is made possible by a centralized employer-sponsored agency that coordinates bargaining for hospitals - the Ontario Hospital Association (OHA). This centralized system has a pervasive impact on all settlements within this sector since locals or hospitals that opt out of central bargaining seldom do better or worse than those in central bargaining. Rogue locals and hospitals are almost always brought into line with the central settlement by arbitrators. ${ }^{7}$ This particular use of arbitration as an enforcement mechanism is a second way in which this contributes to the presence of a chilling effect.

TABLE 3

Hospital Labour Disputes Arbitration Act (HLDAA) Settlements (1984-1993)

\begin{tabular}{lcc}
\hline & Mean Arbitration Rate & Number of Settlements \\
\hline Hospitals & .472 & 4269 \\
Nursing Homes & .349 & 2656 \\
Hospital Services & .114 & 70 \\
Total HLDAA & .422 & 6995 \\
\hline
\end{tabular}

While the Nursing Home sub-sector has no parallel central structure and does not encounter the same amount of pressure to arbitrate as that engendered by the hospital structure, there are nonetheless several large companies that operate in this sector which have the potential to restrict

7. If an arbitrator were to award either more or less to an opted-out local or hospital, the tightly knit system of centralized bargaining would quickly unravel. Because the unit of observation is the local hospital and union, the centralized structure of bargaining magnifies any chilling effect since all local opted-in hospitals and unions must arbitrate even if they are not direct participants. 
the range of settlement outcomes. It should also be noted, however, that out of a concern that a precedent setting settlement could occur within this sector, the Ontario Hospital Association monitors settlements very closely and is in frequent contact with and exchanges information with many of the larger operators within this sector. The smaller hospital services sector is closer to a private sector model because many of these services are contracted-out to private sector firms to provide heating, laundry and food services.

Given the differences in structure and ownership within these three sub-sectors, it is hypothesized that the hospitals will utilize arbitration more than the other two sub-sectors. Table 3 shows that hospitals do indeed have the highest arbitration rate, which suggests that central bargaining aggravates the chilling effect of arbitration. Not surprisingly, the small hospital services sub-sector has an arbitration rate much closer to the private sector strike rate. $^{8}$

This raises the question of whether or not the observed chilling effect is the result of the legislation (no strike), or due to the centralized approach to bargaining in this sector. ${ }^{9}$ To examine this issue, we compared bargaining outcomes in this sector to those of the construction industry in which bargaining is centralized, but with the right to strike. The regression results found in Table 2 show that a lower rate of impasse exists for the construction industry than for the general private sector rate and that this difference is significant ( 3.8 percent). This point is worth noting because this industry is governed by a separate section of the Ontario Labour Relations Act which not only requires a common expiry date for all agreements in the Industrial, Commercial and Institutional (ICI) sectors of the industry, but also requires that all unions bargain on a province-wide basis with a respective council of employers. Also, this is an industry that has a very strong tradition of pattern bargaining and a well-established pecking order among the trades that set the parameters within which most settlements are likely to fall. Therefore, it seems that the presence of a central bargaining mechanism by itself does not $a$ priori contribute to a greater level of impasse. It is only when such a bargaining structure exists within a no-strike sector that significantly higher levels of impasse appear to be reached.

A third approach to an analysis of the chilling effect is to look at variation in its effects by size of bargaining unit. It is hypothesized that smaller

8. However, regression results indicate that all three sub-categories experienced significantly higher impasse rates than the reference category of OLRA.

9. For a discussion of international trends in the decentralization of collective bargaining, see Katz (1993). 
bargaining units will use arbitration proportionately more than larger units when each is compared to its right-to-strike counterparts. This effect is due to the lack of strike power in most small units (Marginson 1984). We estimate this effect by calculating a usage ratio for each size category. ${ }^{10}$

Using this methodology, the less than 21 employees' category displays the largest difference between sectors, and the 500 or more category the smallest at 9.5 and 3.5 respectively. This means that the smallest bargaining units are 9.5 times more likely to have an impasse under an arbitration law than if they negotiated under a law providing for the right to strike. This increased usage increases the probability of inducing a narcotic effect or dependency on arbitration.

A fourth way to illustrate the possible chilling effect of interest arbitration on bargaining is to examines impasse rates of selected unions that have bargaining units under both strike and arbitration laws (Table 4). This approach controls for union differences between strike and no-strike sectors by taking advantage of a behavioural property of public sector unions. Typically, public sector union staff representatives are responsible for bargaining units (union locals) under more than one bargaining law. ${ }^{11}$ It also permits a look at the possible dependency effect of arbitration whereby after repeated arbitration usage, negotiators lose the ability to negotiate. If there is a dependency effect, then union negotiators ought to display similar behavioural patterns under both strike and arbitration laws. Alternatively, if the arbitration law is the true cause of the observed chilling effect, then there should be significant differences in union staff representative behaviour between strike and arbitration sectors. By comparing mean impasse rates between strike and arbitration sectors by union, Table 4 reveals significant differences for all of these unions except for the OPEIU,12 the union with the smallest proportion of activity in the arbitration sector $(5.7 \%)$. Even predominately, private sector unions such as the UFCW, IUOE, and CUOE reveal significantly higher impasse rates when negotiating under arbitration laws.

It is also noteworthy that unions with a high proportion of arbitration activity appear to have higher strike rates. ${ }^{13}$ This finding is supportive of a

10. Ratio is defined as: $\{$ arbitration usage / strike usage $\}=\{\%$ arbitrations $/ \%$ strikes $\}$.

11. For an examination of these laws see Adams (1981).

12. Note that the OPEIU also had higher impasse rates in the arbitration sector and is significant in a one-tail test $(\mathrm{p}<.05)$.

13. If a dichotomy is created by placing those unions with a relatively high proportion of arbitration activity into one category (ONA, SEIU, OPSEU, CUOE) and those with low arbitration activity in a second category (CUPE, UFCW, OPEIU, IUOE), the former category has a significantly higher strike rate. 
TABLE 4

Mean Union Impasse Rates by Strike or Interest Arbitration Law (Number of Bargaining Units in Parenthesis)

\begin{tabular}{|c|c|c|c|c|}
\hline Union & Strike Law & Arbitration Law & " $t$ " Stat. & $\begin{array}{c}\text { Proportion of } \\
\text { Activity in } \\
\text { Arbitration Sector }\end{array}$ \\
\hline ONA & $\begin{array}{l}.070 \\
(357)\end{array}$ & $\begin{array}{c}.460 * * * \\
(1987)\end{array}$ & 22.19 & 84.8 \\
\hline SEIU & $\begin{array}{l}.052 \\
(882)\end{array}$ & $\begin{array}{c}.456^{* * * *} \\
(2182)\end{array}$ & 30.99 & 71.2 \\
\hline OPSEU & $\begin{array}{c}.072 \\
(1093)\end{array}$ & $\begin{array}{c}.434 * * * \\
(571)\end{array}$ & 16.32 & 34.3 \\
\hline CUPE & $\begin{array}{c}.025 \\
(5051)\end{array}$ & $\begin{array}{c}.425 * * * \\
(1455)\end{array}$ & 30.49 & 22.4 \\
\hline UFCW & $\begin{array}{c}.058 \\
(1766)\end{array}$ & $\begin{array}{c}.391 * * * \\
(156)\end{array}$ & 8.42 & 8.1 \\
\hline CUOE & $\begin{array}{l}.027 \\
(262)\end{array}$ & $\begin{array}{c}.328 * * * \\
(180)\end{array}$ & 8.25 & 40.7 \\
\hline OPEIU & $\begin{array}{l}.022 \\
(924)\end{array}$ & $\begin{array}{r}.089 * \\
(56)\end{array}$ & 1.75 & 5.7 \\
\hline IUOE & $\begin{array}{l}.035 \\
(830)\end{array}$ & $\begin{array}{r}.080 * * \\
(262)\end{array}$ & 2.52 & 24 \\
\hline
\end{tabular}

$* \mathrm{p}<.10$ (critical $\mathrm{t}=1.645$, two-tailed test); $* * \mathrm{p}<.05$ (critical $\mathrm{t}=1.960$, twotailed test); $* * * \mathrm{p}<.01$ (critical $\mathrm{t}=2.576$, two-tailed test)

Legend:

ONA: Ontario Nurses Association

SEIU: Service Employees International Union

OPSEU: Ontario Public Service Employees Union

CUPE: Canadian Union of Public Employees

UFCW: United Food and Commercial Workers

IUOE: International Union of Operating Engineers

CUOE: Canadian Union of Operating Engineers

OPEIU: Office and Professional Employees International Union

dependency or narcotic effect whereby "arbitration" unions' inability to freely negotiate settlements spills over into the strike sector. Thus, while interest arbitration exerts a powerful influence over union bargaining behaviour, this effect appears to be greater the more the union operates in the arbitration sector as a proportion of total activity. 


\section{CONCLUSIONS}

This comprehensive data set has allowed researchers to look at the dispute resolution patterns of all bargaining units in the province of Ontario over a 10-year period. What have we learned from this? A central finding is that bargaining units covered by legislation requiring compulsory interest arbitration arrive at impasse 8.7 to 21.7 percent more often than do bargaining units in the right to strike sectors. Even after controlling for legislative jurisdiction, union, bargaining unit size, occupation, agreement length, time trend, and part-time status, strong evidence was found that compulsory arbitration has a chilling effect on the bargaining process. This failure to arrive at a negotiated settlement is particularly acute in the health care sector, especially among hospitals. Our results call into question the use of interest arbitration in a central bargaining context. The centralized structure appeared to exacerbate the negative impact of the chilling effect.

On the one hand, the 1984-93 period under study in this paper is atypical of public sector bargaining given the financial stresses and restructuring policy imperatives of governments of all political stripes. One could argue, therefore, that the results are not readily applicable to other North American jurisdictions. On the other hand, an important test of a system of dispute resolution is its ability to perform effectively under stress. The analysis of this paper suggests that conventional interest arbitration during this period in Ontario, when put to the test, failed to produce a satisfactory rate of freely agreed settlements. We found evidence that arbitration exerted a powerful influence over union bargaining behaviour by increasing rates of impasse. It was also significant that this effect was greater the more the union operates in the arbitration sector as a proportion of total bargaining activity. This finding is supportive of a dependency effect whereby a union's high usage of arbitration fosters an inability to freely negotiate settlements.

\section{】 REFERENCES}

ADAMS, George. 1981. "The Ontario Experience with Interest Arbitration." Interest Arbitration. J. Weiler, ed. Toronto: Carswell.

ADAMs, Roy. 2002. "Implications of the International Human Rights Consensus for Canadian Labour and Management." Canadian Labour and Employment Law Journal, No. 1, 119-139.

AdELl, Bernard, Michel Grant, and Allen PonAK. 2001. Strikes in Essential Services. Kingston, Ont.: IRC Queens Press.

Currie, Janet and Sheena McConnell. 1991. "Collective Bargaining in the Public Sector: The Effect of Legal Structure on Dispute Costs and Wages." American Economic Review, Vol. 81, No. 4, 693-718. 
Cutcher-Gershenfeld, Joel, Patrick McHugh and Donald Carter. 1996. "Collective Bargaining in Small Firms: Preliminary Evidence of Fundamental Change." Industrial and Labor Relations Review, Vol. 49, No. 2, 195213.

Gramm, Cynthia. 1987. "New Measures of the Propensity to Strike During Contract Negotiations, 1971-1980." Industrial and Labor Relations Review, Vol. 40, April, 406-417.

Gross, James, ed. 2003. Workers' Rights as Human Rights. Ithaca, N.Y.: Cornell University Press.

Gunderson, Morley, John Kervin, and Frank ReID. 1986. "Logit Estimates of Strike Incidence from Canadian Contract Data." Journal of Labor Economics, Vol. 4, April, 257-276.

HebDOn, Robert. 1996. "Public Sector Dispute Resolution in Transition." Public Sector Employment in a Time of Transition. D. Belman, M. Gunderson, and D. Hyatt, eds. Madison, Wisc.: Industrial Relations Research Association, 85-125.

HEBDON, Robert and Robert STERN. 1998. "Tradeoffs among Expressions of Industrial Conflict: Public Sector Strike Bans and Grievance Arbitrations." Industrial and Labor Relations Review, Vol. 51, No. 2, 204-221.

HeBdon, Robert and Robert StERn. 2003. "Do Public Sector Strike Bans Really Prevent Conflict?" Industrial Relations, July, 493-512.

ICHNIOWsKi, Casey. 1982. "Arbitration and Police Bargaining: Prescriptions for the Blue Flu." Industrial Relations, Vol. 21, No. 2, 149-167.

JACOBY, Sanford M. and Anil Verma. 1992. "Enterprise Unions in the United States." Industrial Relations, Vol. 31 No. 1, 137-171.

KATZ, Harry C. 1993. "The Decentralization of Collective Bargaining: A Literature Review and Comparative Analysis." Industrial and Labor Relations Review, Vol. 47, No. 1, 3-22.

LESTER, Richard A. 1984. Labor Arbitration in State and Local Government: An Examination of Experiences in Eight States and New York City. Princeton, N.J.: Industrial Relations Section, Firestone Library, Princeton University.

Lund, John and Cheryl Maranto. 1996. "Public Sector Labor Law: An Update." Public Sector Employment in a Time of Transition. D. Belman, M. Gunderson, and D. Hyatt, eds. Madison, Wisc.: Industrial Relations Research Association, 21-39.

MaddalA, G. S. 1983. "Limited Dependent and Qualitative Variables." Econometrics. Cambridge, U.S.: Cambridge University Press.

Marginson, Paul. 1984. "The Distinctive Effects of Plant and Company Size on Workplace Industrial Relations." British Journal of Industrial Relations, Vol. 22, No. 1, 1-14.

McConnell, Sheena. 1987. "Cyclical Fluctuations in Strike Activity." Industrial and Labor Relations Review, Vol. 44, No. 1, 130-143.

Olson, Craig. 1986. "Strikes, Strike Penalties, and Arbitration in Six States." Industrial and Labor Relations Review, Vol. 39, No. 4, 539-551. 
Olson, Craig. 1994. "Final Offer versus Conventional Arbitration Revisited: Preliminary Results from the Lab.” Unpublished manuscript, University of Wisconsin-Madison.

PonAK, Allen M. and Loren FALKEnBerg. 1989. "Resolution of Interest Disputes." Collective Bargaining in Canada. A. S. Sethi, ed. Scarborough, Ont.: Nelson Canada.

Rose, Joseph. 1994. "The Complaining Game: How Effective is Compulsory Interest Arbitration?" Journal of Collective Negotiations, Vol. 23, No. 3, 187-202.

Rose, Joseph and Michael PiczaK. 1996. "Settlement Rates and Settlement

Stages in Compulsory Interest Arbitration." Relations Industrielles/Industrial Relations, Vol. 51, No. 4, 643-664.

STERn, James. 1966. Fact Finding under Wisconsin Law. Madison, Wisc.: University of Wisconsin Press.

Swimmer, Gene, ed. 2001. Public Sector Labour Relations in an Era of Restraint and Restructuring. Don Mills, Ont.: Oxford Press.

WARrian, Peter. 1995. The End of Public Sector Industrial Relations in Canada? The Coming Challenges for Labour and Management. Toronto: KPMG Centre for Government Foundation.

WARrian, Peter. 1996. Hard Bargains: Transforming Public Sector LabourManagement Relations. Toronto: McGilligan Books.

\section{RÉSUMÉ}

\section{La régulation du conflit dans les relations du travail : l'expérience du secteur public de l'Ontario (1984-1993)}

La solution efficace des conflits dans le secteur public fortement syndiqué au Canada continue à retenir l'intérêt des chercheurs et des décideurs publics. Une préoccupation centrale de nos jours porte sur les procédures de solution des conflits inhérents à la restructuration gouvernementale dans le secteur des services en Amérique du Nord. Au Canada, dans un milieu syndiqué, trois formes de restructuration du secteur public ont été répertoriées impliquant soit une approche coopérative, soit une approche « opposionniste », ou bien celle de l'imposition d'un règlement par voie de législation (Swimmer 2001). Étant donné un tel contexte de restructuration, un besoin plus urgent se présente alors d'une analyse des procédures de solution de conflits dans le secteur public. Par exemple, l'arbitrage des différends, qui est la manière habituelle de solutionner les conflits dans le secteur public en général, fait de plus en plus l'objet d'un examen rigoureux à titre de mécanisme efficace de règlement des conflits suite à des changements fondamentaux des conditions de travail (Rose 
1994 ; Lund et Maranto 1996 ; Hebdon 1996 ; Warrian 1996 ; Adell, Grant et Ponak 2001). Nous ré-évaluons l'efficacité de l'arbitrage à travers les diverses législations qui encadrent la solution des conflits dans le secteur public. En reprenant un ensemble de données semblable à celui retenu par Rose et Piczak (1996), nous procédons à une analyse de régression multivariée plus rigoureuse et, en ventilant les données, nous jetons un éclairage sur les aspects plus comportementaux de l'arbitrage obligatoire.

L'arbitrage obligatoire : un cadre théorique. L'arbitrage obligatoire des différends a fait l'objet de recherche en Amérique du Nord, un contexte où ce mécanisme se présente comme une dernière possibilité parmi plusieurs pour apporter une solution définitive aux mésententes impliquant des fonctionnaires dont les services sont qualifiés d'essentiels par des lois et des agences administratives au niveau du gouvernement fédéral, de l'État ou d'une province. L'arbitrage n'est pas la seule option offerte au lieu du recours à la grève chez les employés du secteur public. Par exemple, aux États-Unis, la plupart des conflits dans le secteur public se terminent par une sorte de commission d'enquête ou par une médiation qui ne lie pas les parties (Hebdon et Stern 2003). Au Canada, le dernier recours, lorsque l'impasse persiste, consiste soit à offrir un droit limité à la grève, soit à recourir à l'imposition de l'arbitrage obligatoire, ou bien le choix entre l'arbitrage ou le recours à la grève (Adell, Grant et Ponak 2001).

Les travaux de recherche ont retenu plusieurs critères afin d'évaluer l'efficacité de la solution des conflits : les perceptions des parties, la fréquence du recours à un mécanisme et son impact sur la négociation collective; l'aptitude à réduire le conflit et à empêcher les grèves; enfin, le taux de succès de la solution des conflits (Stern 1966 ; Adell, Grant et Ponak 2001).

Les données et les méthodes. Pour effectuer cette analyse, nous avons retenu comme principale base de données celle du ministère du Travail de l'Ontario qui porte sur 42926 négociations conduites en Ontario entre les années 1984 et 1993. Les données couvrent toutes les unités d'accréditation de toutes les catégories au plan de la taille dans le secteur privé (incluant celui de la construction) et également dans le secteur public provincial au complet pour la période allant de 1984 à 1993. Les instances de règlement sont regroupées sous deux catégories mutuellement exclusives : celles réglées après une impasse (une grève, un arbitrage de différends ou une législation de retour au travail); celles négociées librement (avec l'assistance directe ou non d'une tierce partie).

Conclusion. Cet ensemble de données d'une grande portée permet aux chercheurs de jeter un regard sur les modèles de solution des conflits de toutes les unités d'accréditation de l'Ontario au cours d'une période de dix ans. Qu'avons-nous retenu de tout cela ? Une conclusion fondamentale est à 
l'effet que les unités de négociation couvertes par la loi qui requiert l'arbitrage obligatoire des différends font face à une impasse dans une proportion de 8,7 à 21,7 pour cent plus grande que les unités des secteurs avec droit de grève. Même après avoir tenu compte de la juridiction de la législation, de la centrale syndicale, de la taille de l'unité de négociation, de l'occupation, de la durée de la convention, de la tendance dans le temps et du statut de temps partiel, il devient fort évident que l'arbitrage obligatoire a un effet de refroidissement sur le processus de négociation. L'impossibilité d'en arriver à un règlement négocié est particulièrement prononcée dans le secteur de la santé, plus particulièrement dans les établissements hospitaliers. Nos résultats nous invitent à remettre en question le recours à l'arbitrage obligatoire dans un contexte de négociation centralisée : la structure centralisée semblait aggraver cet effet de refroidissement.

D’un autre côté, la période 1984-1993 envisagée par cette étude reflète bien la situation du secteur public, étant donné les contraintes financières et les impératifs politiques de restructuration des gouvernements de toute couleur politique. Par conséquent, on peut prétendre que ces conclusions ne sont pas directement applicables à d'autres juridictions en Amérique du Nord. Notre analyse laisse croire que l'arbitrage conventionnel des différends, une fois mis à l'essai, ne réussit pas à déboucher sur un taux satisfaisant d'ententes à l'amiable. Nous pouvons soutenir de façon évidente que l'arbitrage a exercé une influence marquée sur le comportement de négociation des syndicats en augmentant le taux de mésententes. L'effet d'influence ainsi observé devient d'autant plus significatif que le syndicat œuvre dans le secteur de l'arbitrage et qu'il représente une proportion de l'activité totale de négociation. Cette observation apporte un support à l'effet de dépendance par lequel un recours à l'arbitrage de la part d'un syndicat accentue une inaptitude à négocier librement des ententes. 